\title{
Histological Assessment of Palatal Donor Site Wound Healing after Application of Moringa oleifera Lamarck Leaf Extract in Rats
}

\author{
Amaliya Amaliya ${ }^{1}$ Regina Kumala Muhaimina² \\ ${ }^{1}$ Department of Periodontology, Dental Faculty, Universitas \\ Padjadjaran Bandung, West Java, Indonesia \\ ${ }^{2}$ Ministry of Defence, Health Division, the Republic of Indonesia, \\ Jakarta, Indonesia \\ ${ }^{3}$ Faculty of Pharmacy, Universitas Jenderal Ahmad Yani, Cimahi, \\ West Java, Indonesia
}

\author{
Agus Susanto ${ }^{1} \quad$ Afifah B. Sutjiatmo ${ }^{3}$
}

\begin{abstract}
Address for correspondence Amaliya Amaliya, DDS, MSc, Department of Periodontology, Dental Faculty, Universitas Padjadjaran, Jalan Sekeloa Selatan no. 1 Bandung 40132,West Java, Indonesia (e-mail: amaliya@fkg.unpad.ac.id).
\end{abstract}

Eur J Dent 2019;13:248-254

\begin{abstract}
Objective Palatal excisional wound healing in 60 Sprague-Dawley rats was studied for a period of 14 days.

Materials and Methods The wounds were made with a punch biopsy instrument with a diameter of $4 \mathrm{~mm}$. After wounding, the test groups received a topical gel of Moringa oleifera Lamarck $2 \%$ or $4 \%$ leaf extract, whereas control groups received povidone iodine gel and hydroxypropyl methylcellulose (HPMC 4\%). Three rats were killed at $0,3,7,10$, and 14 days after wounding from each allocated group. The wounds

Keywords

- open wound

- healing

- histological assay

- Moringa oleifera

Lamarck were assessed at different control times and light microscopy was employed to view serial sections from blocks with magnification.

Results Histological examination revealed that group treated with M. oleifera Lamarck $4 \%$ leaf extract showed the highest fibroblast synthesis and collagen deposition.

Conclusion This study suggests that $M$. oleifera Lamarck leaf extract could be developed as a therapeutic agent for wound healing.
\end{abstract}

\section{Introduction}

Palatal keratinized gingiva is a common site to obtain a free soft-tissue graft for gingival augmentation procedures, but often leads to postoperative morbidity because of the open wound. ${ }^{1}$ Inconvenience caused by pain, postsurgical bleeding, and necrotizing tissue may arise after harvesting the palatal graft, therefore, it is necessary to enhance healing time when the palatal donor site is required for repeated procedures. ${ }^{2}$

After harvesting a palatal free graft, an open wound devoid of epithelium is created, extending deep into the connective tissue and/or bone. This wound type requires a significant amount of new tissue formation with secondary intention healing. ${ }^{3.4}$ Postsurgical mechanical plaque control may be difficult to perform, thus compromising the healing process. ${ }^{5,6}$ A variety of antimicrobial agents have been used to enhance epithelial healing process, thereby preventing infection and chronicity of the wound. Unfortunately, microbes change their metabolism and genetic structure to acquire resistance against the antimicrobial agents used in the treatment of infections. ${ }^{7,8}$ To overcome microbial drug resistance, many studies were performed to develop alternative and novel drugs.

In Indonesia, plants has one of the most extensive floras in the world with more than 20,000 species and a large proportion of the population utilizes medicinal plants as remedy of infectious diseases. ${ }^{9}$ Antibacterial, anti-inflammatory, and wound healing activity of plant extracts of Indonesian medicinal plants have been reported in the literature, but the vast majority has yet to be investigated.

One of the most studied plant is Moringa oleifera Lamarck., native to the Asian subcontinent and Arabia, often considered as an indigenous Indonesian species. ${ }^{10}$ Known as Kelor by local people, it has been used by Indonesians in Sulawesi, 
Java and East Nusa Tenggara as fertilizers, fodder, food, fruit ripening, glue, medicinal, rituals, seed, skin care, water purification, and support for vine crops. ${ }^{11}$ The leaves of this plant have been reported to contain, vitamin $C, \beta$-carotene, protein, calcium, potassium, as well as flavonoids, phenolics and carotenoids and have antimicrobial, antifungal, and wound healing activities. ${ }^{12,13} \mathrm{M}$. oleifera extract has been documented to have antibacterial effect against oral pathogens, antibiofilm, and antifungi. ${ }^{14-17}$ Furthermore, treatment by $M$. oleifera extract can reduce IL1- $\beta$ and TNF- $\alpha$ increased in the gingival tissue in a model of periodontitis in rat. ${ }^{18}$

This study was designed to explore the healing effects of topically applied gel prepared from M. oleifera Lamarck leaves extracts in rat palatal wound.

\section{Materials and Methods}

The experimental design and protocols were reviewed and approved by Ethics Committee in Hasan Sadikin Hospital, Bandung, West Java-Indonesia (33/UN6C10/2018).

\section{Plant Material and Extract Preparation}

M. oleifera Lamarck (Moringaceae) leaves were collected in April 2017 from Kefamenanu, East Nusa Tenggara at $9^{\circ} 26^{\prime} 48^{\prime \prime} \mathrm{S} 124^{\circ} 28^{\prime} 41^{\prime \prime} \mathrm{E}$ and at $50 \mathrm{~m}$ above sea level. It was authenticated with collection number 049/HB/02/2017 deposited in Herbarium of Plant Taxonomy Laboratory, Department of Biology, Faculty of Math and Nature Sciences, Universitas Padjadjaran Jatinangor, West Java, Indonesia.

\section{Preparation of Ethanolic Extracts of M. oleifera}

The fresh leaves were collected, surface sterilized, sun dried for 7 days on ground. The powdered material $(1.5 \mathrm{~kg})$ was exhaustively extracted (3 cycles/h) with $95 \%$ ethanol in Soxhlet apparatus by continuous hot extraction. After each extraction, the solvent was recovered using flash evaporator, and the extract was concentrated under reduced pressure. Then the crude extract was dissolved in the solvent and stored in air-tight glass bottles at $4^{\circ} \mathrm{C}$ and later redissolved in their respective solvents to the desired concentrations for the various experiments.

\section{Gel Preparation}

M. oleifera leaf extract gel 2 and $4 \%$ were made by dissolving 1 gram and 2 grams extract in $5 \mathrm{~mL}$ of aquades with an ultrasonic instrument and subsequently mixed with 50 grams gel basis (HPMC 4\%) as vehicle until it became homogeneous.Ethanol extract and gel were prepared in the Laboratory of Pharmacy, Universitas Jenderal Ahmad Yani, Cimahi, West Java, Indonesia.

\section{Animals}

Sixty male Sprague-Dawley rats (200-300 g) were used to carry out the study. One week before the experimental procedures, the animals were housed and adapted at air-conditioned animal laboratory room $\left(22 \pm 3^{\circ} \mathrm{C}\right)$ with 12 -hour light and dark cycle. The rats were fed with commercial normal rodent pellet and filtered water ad libitum. All of the animals received humane care according to the criteria outlined in the Guide for the Care and the Use of Laboratory Animals prepared by the National Academy of Science and published by the National Institute of Health. The ethics regulations were followed in accordance with national and institutional guidelines for the protection of the animals' welfare during experiments. ${ }^{19} \mathrm{All}$ of the experimental procedures were performed in Laboratory of Experimental Animal, Faculty of Medicine, Universitas Jenderal Ahmad Yani, Cimahi, West Java, Indonesia.

\section{Wound Induction and Experimental Animal Groups}

The animals were randomly divided into four experimental groups ( $n=15$ per group) as follows:

Group I: wounding and Moringa leaf extract gel 2\%, Group II: wounding and Moringa leaf extract gel 4\%, Group III: wounding and povidone iodine gel $10 \%$, and Group IV: wounding and HPMC 4\% (vehicle only).

The animals were anesthetized with an intraperitoneal injection of $10 \%$ Ketamine and a $4-\mathrm{mm}$ mucosal wound was made on a central area of hard palate to the depth of the periosteum using a disposable round stainless steel blade designed for punch biopsy (Mentok Co., Ltd., India) exposing a circular area of bare bone and gingiva was separated by periosteal elevator. ${ }^{20}$ Each group received allocated regimen immediately after the wounding procedures by researcher's assistant once daily for 14 days. The animals were sacrificed with decapitation, assessments were performed at days 0,3 , 7,10 , and 14 days after wound induction.

\section{Histological Assay}

Tissue specimen were excised and immersed at days 0,3 , 7,10 , and 14 after wound induction and preserved in $10 \%$ neutral buffered formalin before tissue processing procedures. The tissue sections embedded in paraffin wax were sectioned in $5 \mu \mathrm{m}$ thickness, followed by dewaxed and rehydrated conventionally. These sections were then stained with hematoxylin and eosin (H\&E) for fibroblast assessment, while Masson's trichrome staining was employed to reveal collagen deposition. The stained samples viewed under the light microscope (Olympus BX 41, United States) at $\times 100$ magnification and then processed with ImageJ software (National Institute of Health, United States).

\section{Statistical Analysis}

All data were subjected to statistical analysis using SPSS 20.0 (SPSS, IBM, New York, NY, United States). Shapiro-Wilk test was employed to determine normality of the data. All values were represented as means \pm SD and were analyzed using analysis of variance (ANOVA) then by Duncan's post-hoc for multiple comparisons ( $p<0.05$ was considered significant).

\section{Results}

All 60 rats survived the surgical procedures with no complications. Findings on each group were evaluated and histological differences were compared between control and experimental groups of section. 
To test the normality of the data, Shapiro-Wilk test was employed, all data was normally distributed. One way analysis of variance(ANOVA) was then performed ( - Tables 1 and $\mathbf{2}$ ), followed by Duncan's post-hoc to measure specific differences between pairs of means ( $\mathbf{- T a b l e s} \mathbf{3}$ and $\mathbf{4}$ ).

In the presence of Moringa 4\%, the growth of fibroblasts and collagen deposition were found to be significantly higher $(p<0.05)$ than in the other group tested.

Three days after injury, the Moringa-treated wound's fibroblasts significantly repopulated the wound area compared with povidone iodine or HPMC groups.

Seven days after injury, wounds treated with Moringa and povidone iodine displayed significantly improved fibroblasts proliferation compared with HPMC group (-Table $\mathbf{1}$ ).

Ten days after injury, fibroblasts were found to be significantly higher in Moringa 4\%-treated groups $(p<0.05)$ than in the other groups tested ( $\boldsymbol{- \text { Fig. }}$ 1).

Histological section showed that in Moringa-treated wounds, fibroblasts migrated faster toward the open wounds than povidone iodine or HPMC-treated ( - Fig. 2 ).

An increased formation of new collagen into the wound area was observed based on the percentage of brightness from Image-J program for all groups tested from days 3 to 14. This behavior was best observed in the Moringa 2 and 4\% groups (-Figs. 3)

\section{Discussion}

The present study was conducted to test the effect of topical application of $M$. oleifera leaves extract on the healing process of excisional wounds with connective tissue deficiency that heals by secondary intention. In wound healing, good tissue growth was defined as a tissue rich in fibroblasts and dense in newly synthesized collagen determined by Masson's trichrome. ${ }^{21}$
Table 3 Duncan post-hoc analysis for fibroblast density

\begin{tabular}{|l|l|l|l|l|}
\hline & \multicolumn{3}{|l|}{ Subset for $\alpha=\mathbf{0 . 0 5}$} \\
\hline Day 3 & $\mathbf{1}$ & $\mathbf{2}$ & \\
\hline Povidone iodine & 18.27 & & \\
\hline HPMC & 20.07 & & \\
\hline Moringa (2\%) & & 24.80 & \\
\hline Moringa (4\%) & & & \\
\hline Significant & 0.152 & 1.000 & \\
\hline Day 7 & $\mathbf{1}$ & $\mathbf{2}$ & \\
\hline HPMC & 25.67 & & \\
\hline Moringa (2\%) & & 35.73 & \\
\hline Moringa (4\%) & & 38.93 & \\
\hline Povidone iodine & & & \\
\hline Significant & 1.000 & 0.067 & \\
\hline Day 10 & $\mathbf{1}$ & $\mathbf{2}$ & $\mathbf{3}$ \\
\hline HPMC & 30.47 & & \\
\hline Moringa (2\%) & & 36.40 & \\
\hline Povidone iodine & & $\mathbf{2}$ & \\
\hline Moringa (4\%) & & 3.000 & \\
\hline Significant & 1.000 & $\mathbf{2}$ & \\
\hline Day 14 & $\mathbf{1}$ & & \\
\hline HPMC & 23.07 & & \\
\hline Moringa (2\%) & & & \\
\hline Povidone iodine & & & \\
\hline Moringa (4\%) & & & \\
\hline Significant & & & \\
\hline
\end{tabular}

Abbreviation: HPMC, hydroxypropyl methylcellulose.

Table 1 Mean fibroblast population after wound

\begin{tabular}{|l|l|l|l|l|l|}
\hline & HPMC & PI & Moringa (2\%) & Moringa (4\%) & $p$-Value \\
\hline Day 3 $( \pm$ SD) & $20(2)$ & $18(3)$ & $24(3)$ & $32(5)$ & $\leq 0.00^{\text {a }}$ \\
\hline Day 7 $( \pm$ SD) & $26(5)$ & $39(3)$ & $36(5)$ & $39(5)$ & $\leq 0.00^{\text {a }}$ \\
\hline Day 10 $( \pm S D)$ & $30(5)$ & $41(5)$ & $36(4)$ & $70(5)$ & $\leq 0.00^{\text {a }}$ \\
\hline Day 10 $( \pm S D)$ & $23(5)$ & $35(5)$ & $32(4)$ & $51(6)$ & $\leq 0.00^{\text {a }}$ \\
\hline
\end{tabular}

Abbreviations: HPMC, hydroxypropyl methylcellulose; PI, povidone iodine; SD, standard deviation.

Note: ANOVA test.

Table 2 Collagen deposition (\%) after wound

\begin{tabular}{|l|l|l|l|l|l|}
\hline & HPMC & PI & Moringa (2\%) & Moringa (4\%) & p-Value \\
\hline Day 3 $( \pm$ SD) & $37.09(4.45)$ & $28.69(4.44)$ & $43.51(4.93)$ & $45.45(2.28)$ & $\leq 0.00^{\text {a }}$ \\
\hline Day 7 $( \pm$ SD) & $40.90(5.11)$ & $48.01(3.87)$ & $45.94(5.64)$ & $63.07(5.27)$ & $\leq 0.00^{\text {a }}$ \\
\hline Day 10 $( \pm$ SD) & $66.67(4.10)$ & $68.69(4.18)$ & $69.50(4.79)$ & $68.61(2.85)$ & $=0.276$ \\
\hline Day 14 $( \pm$ SD) & $68.78(3.97)$ & $71.56(3.91)$ & $74.80(6.25)$ & $74.02(5.68)$ & $=0.08^{\text {a }}$ \\
\hline
\end{tabular}

Abbreviations: HPMC, hydroxypropyl methylcellulose; PI, povidone iodine; SD, standard deviation.

Note: ANOVA test.

aStatistically significant 
Table 4 Duncan post-hoc analysis for collagen density

\begin{tabular}{|l|l|l|l|}
\hline & \multicolumn{3}{|l|}{ Subset for $\alpha=0.05$} \\
\hline Day 3 & 1 & 2 & 3 \\
\hline Povidone iodine & 28.6907 & & \\
\hline HPMC & & 37.0958 & \\
\hline Moringa (2\%) & & & 43.5116 \\
\hline Moringa (4\%) & & & 45.4575 \\
\hline Significant & 1.000 & 1.000 & 0.206 \\
\hline Day 7 & $\mathbf{1}$ & $\mathbf{2}$ & $\mathbf{3}$ \\
\hline HPMC & 40.9063 & & \\
\hline Moringa (2\%) & & 45.9404 & \\
\hline Moringa (4\%) & & 48.0197 & \\
\hline Povidone iodine & & & 63.0797 \\
\hline Significant & 1.000 & 0.262 & 1.000 \\
\hline Day 14 & $\mathbf{1}$ & $\mathbf{2}$ & \\
\hline HPMC & 68.7897 & & \\
\hline Povidone iodine & 71.5617 & 71.5617 & \\
\hline Moringa (4\%) & & 74.0247 & \\
\hline Moringa (2\%) & & 74.8063 & \\
\hline Significant & 0.139 & 0.102 & \\
\hline Abbrevation: & & & \\
\hline
\end{tabular}

Abbreviation: HPMC, hydroxypropyl methyl.

The findings of this present study revealed that the rate of fibroblast proliferation and collagen deposition of the wound were significantly superior following the application of both 2 and 4\% Moringa leaves extract gel, and slower when povidone iodine gel and vehicle only was applied.
M. oleifera extract has been shown to have accelerating effect on wound healing in skin. The ethanol and ethyl acetate extracts of seeds showed significant antipyretic activity in rats, whereas ethyl acetate extract of dried leaves showed significant wound healing activity (10\% extracts in the form of ointment) on excision, incision, and dead space (granuloma) wound models in rats. ${ }^{22}$ The aqueous extract of $M$. oleifera promotes wound healing significantly and wound healing-suppression action of dexamethasone could be overcome. ${ }^{23}$ Activation of fibroblasts, endothelial cells, and macrophages are keys of wound healing in which body cells response to injury. The restoration of structure and function in the wound site is determined by fibroblast proliferation. ${ }^{24}$ Therefore, therapeutic bioactive agents that are able to stimulate fibroblast growth and proliferation may be able to improve or promote wound healing as in the case of the present study, ethanol extract of $M$. oleifera leaves prepared in gel was demonstrated to enhance the proliferation of fibroblast and collagen deposition in palatal rats.

Unlike skin surface, wound located in the oral cavity is surrounding by the unique environmental challenge for the epithelial healing of oral wounds produced during various periodontal procedures, since the oral environment cannot be sterilized from oral bacteria or plaque formation. Therefore, wound surface must be protected from the external environment or infection after periodontal surgery. The donor sites require 2 to 4 weeks to heal with secondary intention resulting in experience of pain and postoperative bleeding. In the present study, more fibroblast and collagen deposition were seen at palatal donor site at days 10 and 14 in which Moringa gel was given.

The mechanisms through which the $M$. oleifera leaves extract accelerates wound healing were further explored by examining whether this extract increased fibroblast

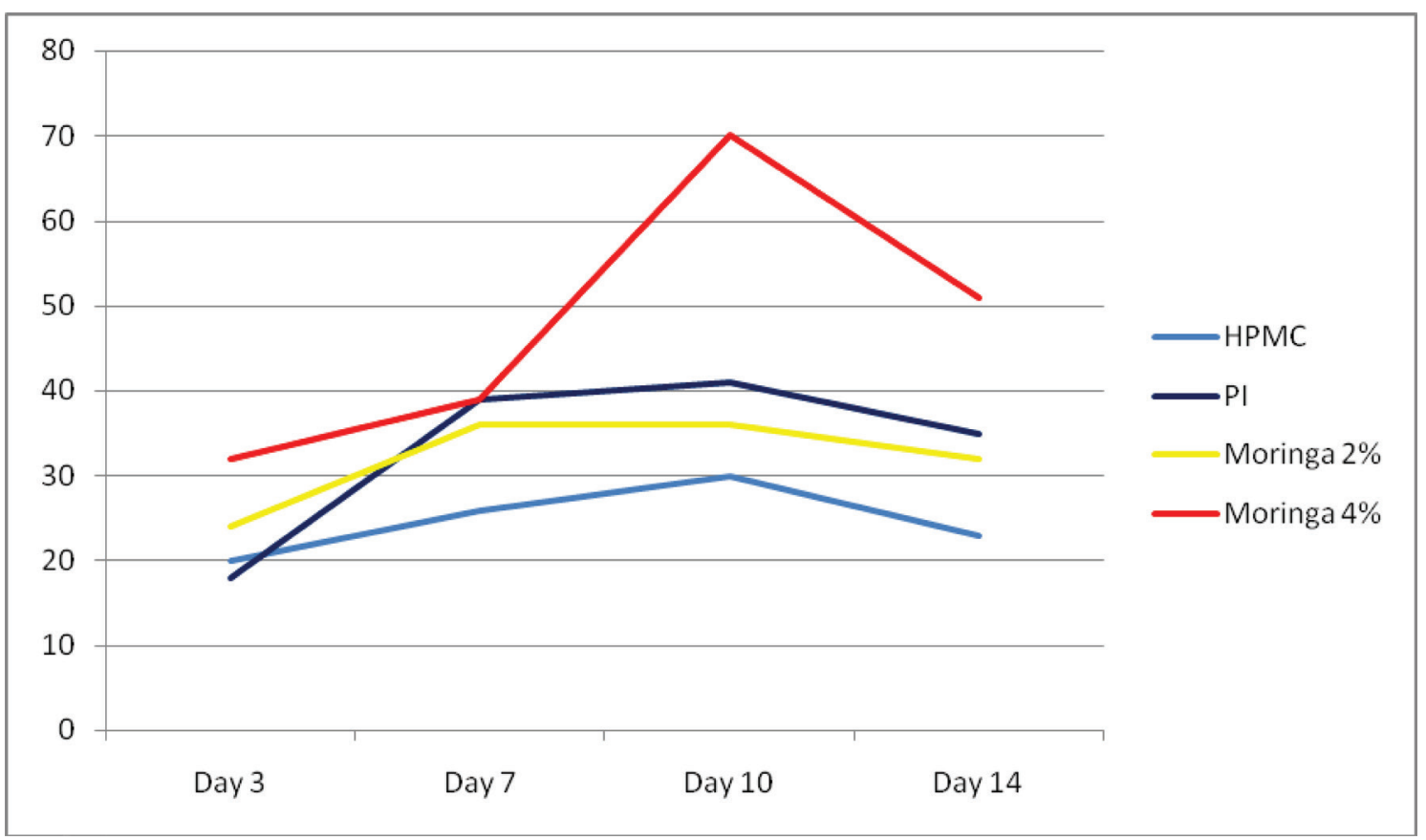

Fig. 1 Fibroblast population after wound. HPMC, hydroxypropyl methylcellulose; PI, povidone iodine. 


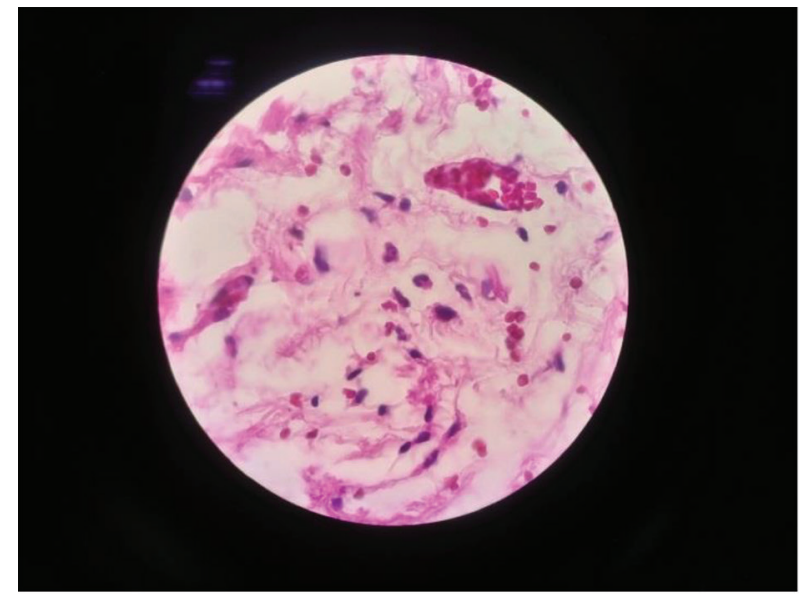

HPMC-treated

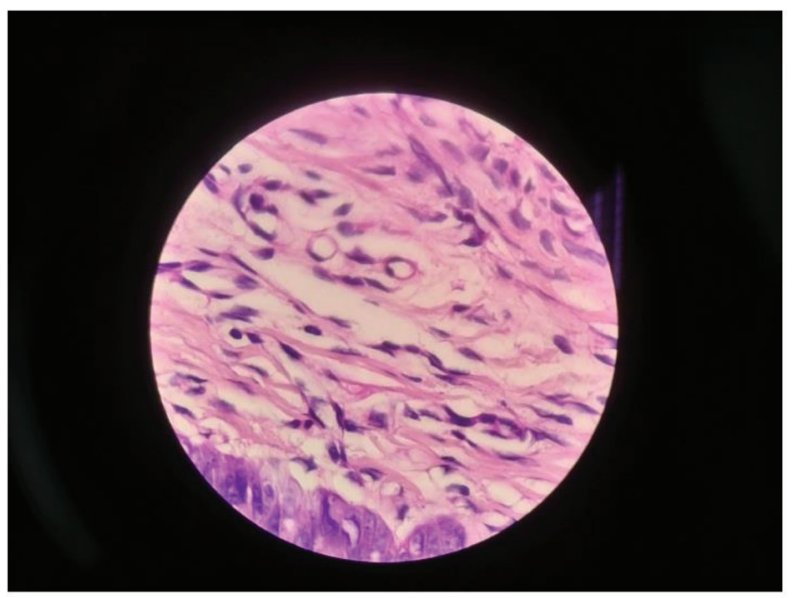

Moringaoleifera $2 \%$-treated

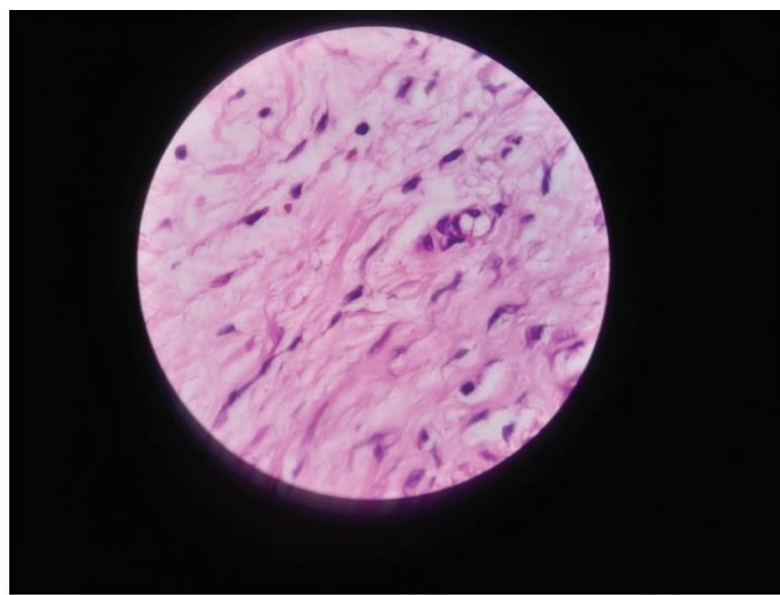

Povidone iodine-treated

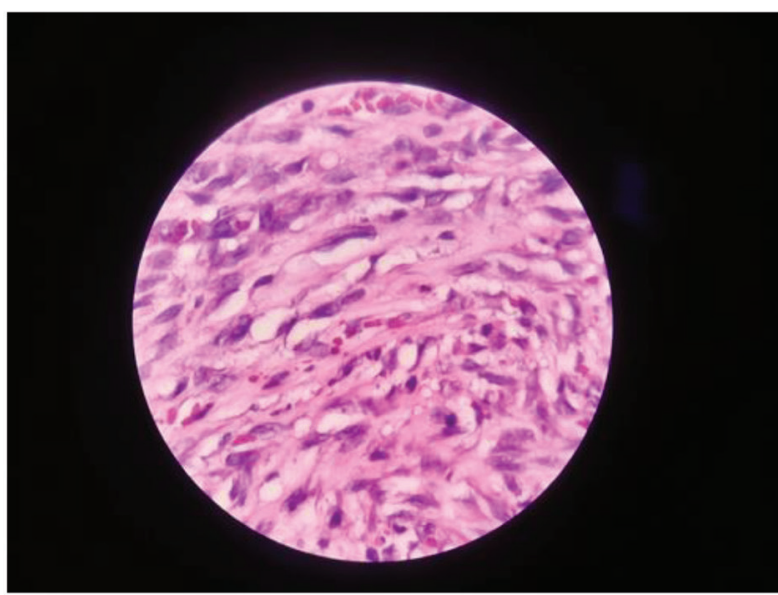

Moringaoleifera 4\%-treated

Fig. 2 Fibroblast at day 10 (magnification 100X). HPMC, hydroxypropyl methylcellulose.

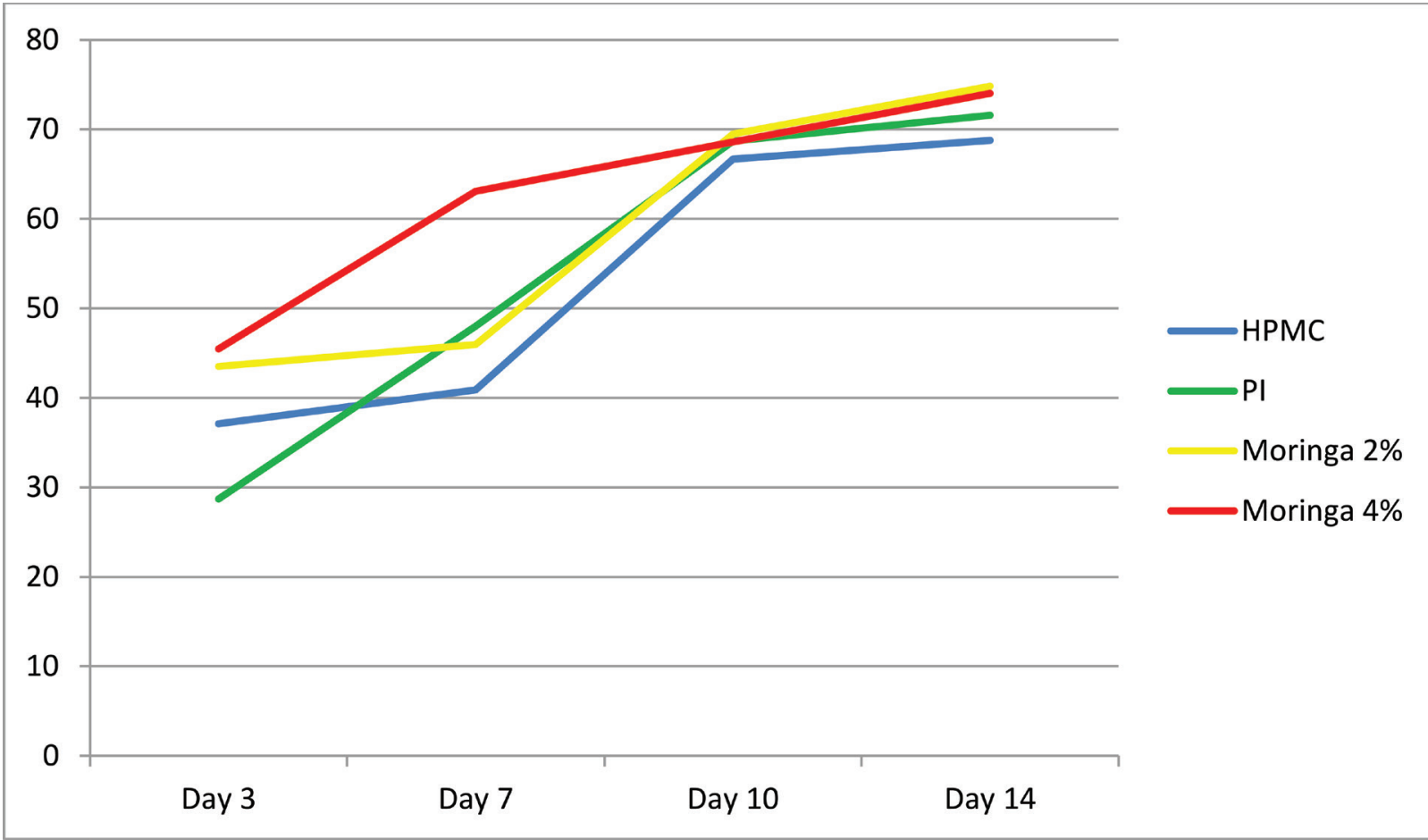

Fig. 3 Collagen density after wound. HPMC, hydroxypropyl methylcellulose; PI, povidone iodine. 


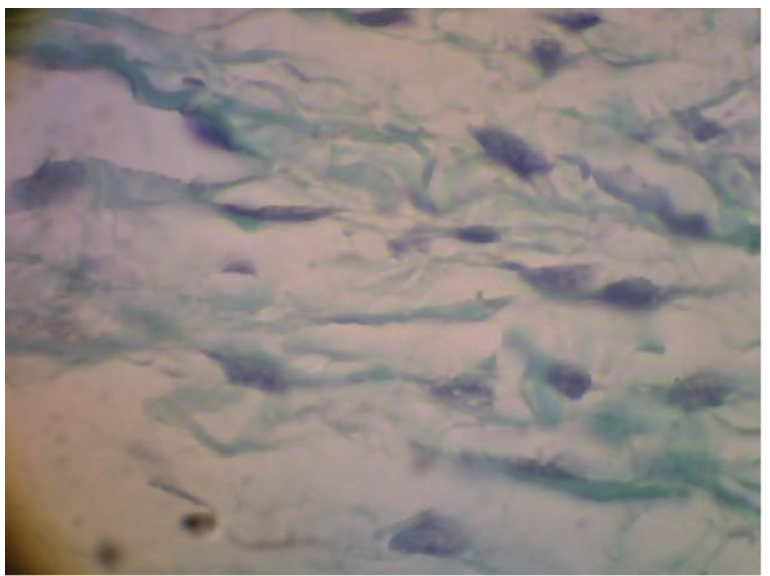

HPMC-treated

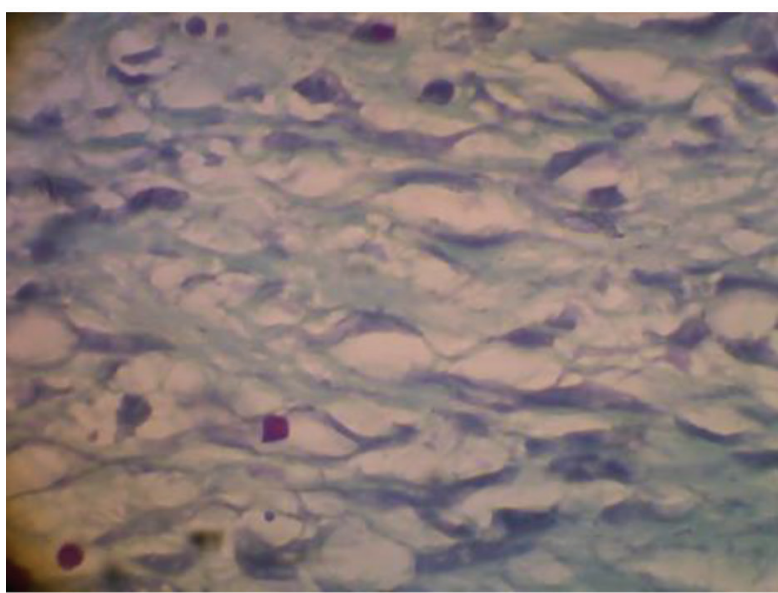

Moringaoleifera $2 \%$-treated

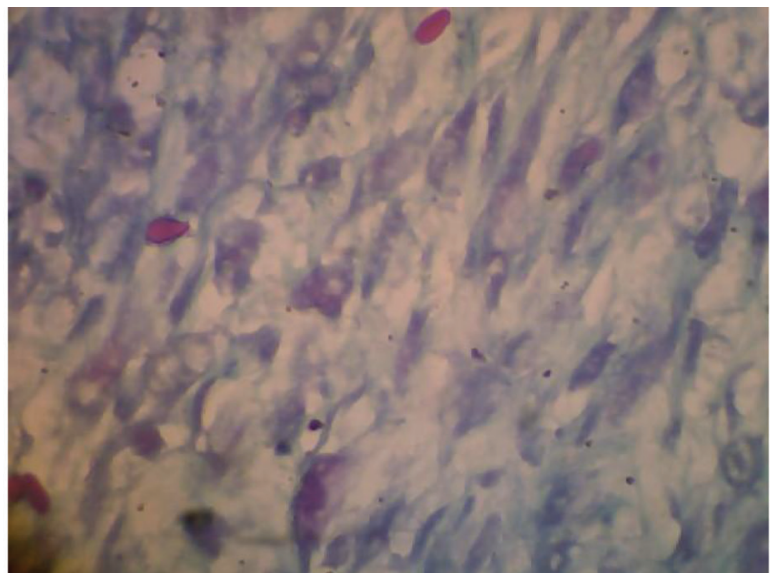

Povidone iodine-treated

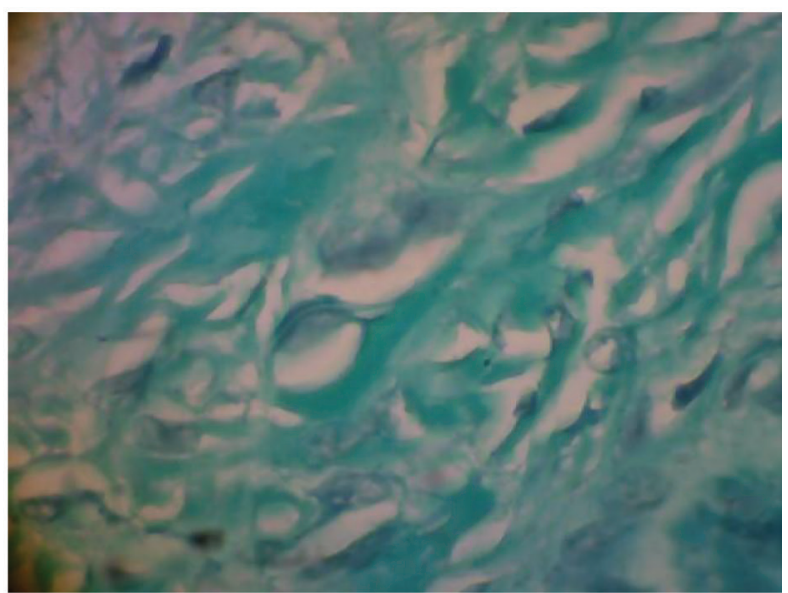

Moringaoleifera 4\%-treated

Fig. 4 Collagen deposition at day 7 (Magnification 100X). HPMC, hydroxypropyl methylcellulose.

migration and collagen deposition in wound tissue. Collagen fibers reached the highest deposition in wounds treated with $M$. oleifera leaves extract $4 \%$. The dispersed blue stain indicated thicker and more mature tissue collagen formation in wounds treated with this extract, suggesting that exposure of $M$. oleifera leaves extract maintained connective tissue architecture through fibroblast migration and ultimately collagen deposition.

Plant used as phytochemical may inhibit bacterial growth by different mechanisms than the presently used antibiotics. Peptides content in $M$. oleifera has an action on membrane disruption of several species of Staphylococcus including MRSA, as well as Streptococcus sp, Eschericia coli and Enterococcus faecalis. ${ }^{25}$ Elgamily et al showed antimicrobial and antifungal potential effects of Moringa leaves extract against oral pathogens. ${ }^{17}$ The leaves of $M$. oleifera plant are known to contain phytochemical compounds as flavonoids, saponins, tannins, and other phenolic compounds that have antimicrobial activities. ${ }^{26-28}$ This would explain sites given Moringa extract were protected from microbial or fungal challenge from oral cavity that may compromise the wound healing.

This study showed wound healing effect of $M$. oleifera leaves extract was comparable with those of povidone iodine in positive control group. Bioactive fraction of $M$. oleifera containing Vicenin-2 compound may contribute to enhance faster wound healing in vitro as shown by Muhammad et al (2013). ${ }^{29}$

In conclusion, within the limitations of the present study: (1) it is confirmed that $M$. oleifera leaves ethanol extract stimulates fibroblast and collagen deposition during the initial phase of wound healing in palatal rats, (2) the leaves extracts can be used to formulate new dental products to accelerate wound healing in oral cavity owing to their antibacterial and anti-inflammatory potentials. However, further studies are required to clarify the optimal concentration and physical stability before its clinical application.

\section{Conflict of Interest}

None declared.

\section{Acknowledgment}

The authors greatly acknowledge Dr. Euis Reni, DDS, MS from Universitas Jenderal Achmad Yani, Cimahi, West Java, Indonesia for her technical assistance in animal, histological, and plant preparation. 


\section{References}

1 Wessel JR, Tatakis DN. Patient outcomes following subepithelial connective tissue graft and free gingival graft procedures. J Periodontol 2008;79(3):425-430

2 Del Pizzo M, Modica F, Bethaz N, Priotto P, Romagnoli R. The connective tissue graft: a comparative clinical evaluation of wound healing at the palatal donor site. A preliminary study. J Clin Periodontol 2002;29(9):848-854

3 Farnoush A. Techniques for the protection and coverage of the donor sites in free soft tissue grafts. J Periodontol 1978;49(8):403-405

4 Nemcovsky CE, Artzi Z, Moses O, Gelernter I. Healing of dehiscence defects at delayed-immediate implant sites primarily closed by a rotated palatal flap following extraction. Int J Oral Maxillofac Implants 2000;15(4):550-558

5 Nooh N, Graves DT. Healing is delayed in oral compared to dermal excisional wounds. J Periodontol 2003;74(2):242-246

6 Kozlovsky A, Artzi Z, Hirshberg A, Israeli-Tobias C, Reich L. Effect of local antimicrobial agents on excisional palatal wound healing: a clinical and histomorphometric study in rats. J Clin Periodontol 2007;34(2):164-171

7 Tenover FC. Mechanisms of antimicrobial resistance in bacteria. Am J Infect Control 2006;34(5 Suppl 1 :S3-S10,discussionS64-S73

8 Stewart PS, Costerton JW. Antibiotic resistance of bacteria in biofilms. Lancet 2001;358(9276):135-138

9 Kusmana C, Hikmat A. Keanekaragamanhayati flora di Indonesia. Jurnal Pengelolaan Sumberdaya Alamdan Lingkungan. Journal of Natural Resources and Environmental Management. 2015;5(2):187-198

10 Ebert AW, Promotion of indigenous vegetables in Asia: conservation and use of selected crops in Indonesia, the Philippines, and Taiwan. In: ISHS Acta Horticulturae 918: XXVIII International Horticultural Congress on Science and Horticulture for People (IHC2010): III International Symposium on Plant Genetic Resources; 2010: 397-403</conf

11 Sabastian G, Dahlia L, Mahrizal M, et al. Ethnobotanical use and commercial potential of Moringa oleifera in Indonesia: an underused and under-recognized species. In: ISHS Acta Horticulturae 1158 : I International Symposium on Moringa 2015: 349-356

12 Siddhuraju P, Becker K. Antioxidant properties of various solvent extracts of total phenolic constituents from three different agroclimatic origins of drumstick tree (. Moringa oleifera. Lam.) leaves. J Agric Food Chem 2003;51(8):2144-2155

13 Oluduro AO. Evaluation of antimicrobial properties and nutritional potentials of. Moringa oleifera. Lam. leaf in south-western Nigeria. Malays J Microbiol 2012;8(2):59-67

14 Rao PK, Anjana M, Lavanya KD, Madhavi Y, Rao TR. In vitro antibacterial screening of selected medicinal plant extracts against oral pathogens. Asian Journal of Experimental Sciences 2009;23(3):479-485
15 Moura MC, Trentin DS, Napoleão TH, et al. Multi-effect of the water-soluble. Moringa oleifera. lectin against. Serratia marcescens. and. Bacillus. sp.: antibacterial, antibiofilm and anti-adhesive properties. J Appl Microbiol 2017;123(4):861-874

16 Alsaraf KM, Abd ST, Husain NS. An antimicrobial activity of. Moringa Oleif. era extract in comparison to chlorhexidine gluconate (in vitro study) Journal of Baghdad College of Dentistry. 2016;28(1):183-187

17 Elgamily H, Moussa A, Elboraey A. El-Sayed H, Al-Moghazy M, Abdalla A. Microbiological assessment of Moringa oleifera extracts and its incorporation in novel dental remedies against some oral pathogens. Open Access Maced. J Med Sci 2016;4(4):585-590

18 Sahrakary M, Nazemian V, Aghaloo M, et al. Treatment by. Moringa oleifera. extract can reduce gingival inflammatory cytokines in the rat periodontal model. Physiology and Pharmacology 2017;21(2):102-109

19 Kilkenny C, Browne W, Cuthill IC, Emerson M, Altman DG; NC3Rs Reporting Guidelines Working Group. Animal research: reporting in vivo experiments: the ARRIVE guidelines. $\mathrm{Br} \mathrm{J}$ Pharmacol 2010;160(7):1577-1579

20 Oda Y, Kagami H, Ueda M. Accelerating effects of basic fibroblast growth factor on wound healing of rat palatal mucosa. J Oral Maxillofac Surg 2004;62(1):73-80

21 Doillon CJ, Silver FH, Olson RM, Kamath CY, Berg RA. Fibroblast and epidermal cell-type I collagen interactions: cell culture and human studies. Scanning Microsc 1988;2(2):985-992

22 Hukkeri VI, Nagathan CV, Karadi RV, Patil BS. Antipyretic and wound healing activities of. Moringa oleifera. Lam. in rats. Indian J Pharm Sci 2006;68(1):124

23 Lambole V, Kumar U. Effect of. Moringa oleifera. Lam. on normal and dexamethasone suppressed wound healing. Asian Pac J Trop Biomed 2012;2(1):S219-S223

24 Clark RA. Fibrin and wound healing. Ann N Y AcadSci 2001;936(1):355-367

25 Suarez M, Haenni M, Canarelli S, et al. Structure-function characterization and optimization of a plant-derived antibacterial peptide. Antimicrob Agents Chemother 2005;49(9):3847-3857

26 Moyo B, Masika PJ, Muchenje V. Antimicrobial activities of. Moringa oleifera. Lam leaf extracts. Afr J Biotechnol 2012;11(11):2797-2802

27 Krishnaiah D, Devi T, Bono A, Sarbatly R. Studies on phytochemical constituents of six Malaysian medicinal plants. J Med Plants Res 2009;3(2):067-072

28 Vinoth B, Manivasagaperumal R, Balamurugan S. Phytochemical analysis and antibacterial activity of. Moringa oleifera. Lam. Int J Res Biol Sci 2012;2(3):98-102

29 Muhammad AA, Pauzi NA, Arulselvan P, Abas F, Fakurazi S. In vitro wound healing potential and identification of bioactive compounds from. Moringa oleifera. Lam. BioMed Res Int 2013; doi:10.1155/2013/974580 